\title{
Audit Committee Accounting Expertise, Analyst Following, and Market Liquidity
}

David B. Farber, Shawn X. Huang, Elaine Mauldin

\begin{abstract}
We study the relation between audit committee accounting expertise, analyst following, and market liquidity. Our main results indicate that analyst following increases subsequent to the appointment of an accounting expert to the audit committee. We also provide evidence that accrual quality, as opposed to audit quality or management earnings forecasts, is the channel through which accounting expertise increases analyst following and improves analyst forecast properties. We also show that audit committee accounting expertise is related to higher trading volume and lower liquidity risk, supporting incentives for greater analyst following. Our study extends prior literature by providing evidence that audit committee accounting expertise enhances firms' information environment beyond the effects it has on financial reporting quality or analysts' forecast properties. Our study also complements the literature on determinants of analyst following and market liquidity, both of which are related to cost of capital. Results from our study should be useful to firms seeking to enhance analyst following and market liquidity.
\end{abstract}

Keywords: analyst following; audit committee accounting expertise; market liquidity

Data Availability: All analyses are based upon publicly available data.

This is the author's manuscript of the article published in final edited form as:

Farber, D. B., Huang, S. X., \& Mauldin, E. (2016). Audit Committee Accounting Expertise, Analyst Following, and Market Liquidity. Journal of Accounting, Auditing \& Finance, 0148558X16663090. https://doi.org/10.1177/0148558X16663090 


\section{Introduction}

In this study, we examine the relation between accounting expertise on the audit committee and analyst following. Boards of directors improve their performance by delegating authority to standing committees, such as the audit committee, that specialize in narrowly defined functions (Klein 1998). We study accounting expertise as a primary feature of audit committee composition that prior research finds is related to enhanced financial reporting (Carcello et al. 2008; Krishnan and Visvanathan 2008; Dhaliwal et al. 2010). We extend prior research by providing a more complete understanding of the effect of audit committee accounting expertise on firms' broader information environment beyond financial reporting, as proxied by analyst following and market liquidity. Understanding the relation between audit committee accounting expertise, analyst following, and market liquidity has important implications for firms seeking greater analyst coverage and lower cost of capital, as well as for regulators concerned with audit committee effectiveness.

Prior research finds that audit committee accounting expertise is associated with greater forecast accuracy and reduced forecast dispersion (Abernathy et al. 2013). ${ }^{1}$ However, it does not necessarily follow that accounting expertise will also lead to increased analyst following. While Lang and Lundholm (1996) show that firms with more informative disclosures have greater analyst following and better forecast properties, Lehavey et al. (2011), in contrast, show that firms with more complex disclosures have greater analyst following but worse forecast properties. As Lang et al. (2003) argue, analyst forecast accuracy could operate independently from analyst following

\footnotetext{
${ }^{1}$ In contrast, Byard, et al. (2006) do not find a significant relation between audit committee independence and analyst forecast accuracy.
} 
because of information gathering by other capital market intermediaries (e.g., buy-side analysts) and/or because firms disclose more information. It is therefore an open empirical question as to whether audit committee accounting expertise impacts analyst following.

Theoretically, Bushman et al. (2004, p. 210) argue that governance mechanisms and analysts are "interrelated information mechanisms," suggesting that analysts likely respond to audit committee composition. Consistent with theory, professional practice standards require analysts to incorporate information from governance disclosures in their decision making (CFA Institute 2005). Prior research demonstrates that analyst following increases with higher Standard \& Poor's rankings of board structure disclosures (Yu 2009). In addition, surveys report that both buy-side and sell-side analysts consider weak corporate governance as one of the two highest indicators of intentional misreporting and over 75 percent of sell-side analysts report that corporate governance is a factor in their decision to cover a company (Brown et al. 2014; Brown et al. 2015).

We hypothesize that analyst following increases after the appointment of accounting experts to the audit committee. Because analysts monitor management (Jung et al. 2012), enhanced monitoring by audit committee accounting experts may reduce analysts' costs to follow a firm, leading to a complementary relation between analysts and audit committee accounting expertise. For example, prior survey research finds analysts report higher confidence in financial reporting quality when an accounting expert is on the audit committee compared to other types of expertise (Dickins et al. 2009). In the spirit of Lang and Lundholm (1996), we also expect analysts to be attracted to firms with audit committee accounting expertise because these firms have higher financial reporting quality than firms with other types of audit committee expertise (Carcello et al. 2008). However, we may not find results consistent with our hypothesis if improved financial reporting associated with audit committee accounting expertise reduces analysts' competitive 
advantage, leading to decreased analyst coverage (Lehavy et al. 2011). Providing further support for analysts' incentives to follow the firm, we also expect greater market liquidity for firms with audit committee accounting expertise because of an improved information environment (Healy et al. 1999).

We execute our tests with a random sample of 460 firms over the period 1998 to 2003 . This time period provides a powerful setting for our study because firms were likely to change their audit committee composition to include, for the first time, members with accounting expertise due to the influence of both the Blue Ribbon Committee (BRC) and the Sarbanes Oxley Act (SOX). For our main test, we construct panel data for the 131 sample firms that appointed an accounting expert to the audit committee during our sample period and use a time series approach to address potential endogeneity issues (Hermalin and Weisbach 2003; Healy et al. 1999). Because the dependent variable (i.e., analyst coverage) is a non-negative integer, we use a Poisson model to estimate our main regression.

We find that analyst following increases after the appointment of an accounting expert to the audit committee, even after controlling for other governance strength, institutional investors, the number of analysts employed by the brokerage firm, analyst effort, firm size, growth, profitability, trading volume, security offerings, return volatility, intangibles, year fixed effects, and firm fixed effects. Our results are robust to using alternative analysis periods, a pooled cross-sectional model, non-accounting expertise, across the pre- and post-Reg FD periods, an alternative measure of governance strength, and across the pre- and post-SOX periods. Our results are also robust to using a Negative Binomial model and a Tobit model to control for the count data nature of analyst following (Rock et al. 2001). 
To provide deeper insights into our main result, we test three potential channels through which accounting expertise could impact analyst following: (i) audit quality, (ii) management earnings forecasts, and (iii) accrual quality. Results indicate that accounting expertise increases analyst following only through the channel of enhanced accrual quality. That is, we find that the impact of the appointment of an accounting expert on analyst following is significantly greater when accrual quality is higher, but no effect from audit quality or management earnings forecasts. In additional tests, we first replicate results from Abernathy et al. (2013), who find that analyst forecast errors and dispersion are lower following the appointment of accounting experts to the audit committee. Extending Abernathy et al. (2013), we find that accounting expertise on the audit committee has a significant economic impact on forecast properties through the accrual quality channel, but not through audit quality or management earnings forecasts.

Despite our efforts to control for known factors related to analysts' decisions and our use of firm fixed effects, results in Brown et al. (2015) suggest that analysts' incentives to follow firms are not clear. We therefore provide evidence about whether accounting expertise generates positive capital market effects. To do so, we assess the relation between accounting expertise and both trading volume and liquidity risk (Liu 2006), factors related to cost of capital. The intuition is that audit committee accounting expertise increases firms' information environment, leading to increased investor interest in firms' stocks. We report a positive (negative) relation between trading volume (liquidity risk) and accounting expertise, suggesting that accounting expertise provides significant capital market benefits beyond enhanced financial reporting, increased analyst following and enhanced analyst forecast properties. These results also support analyst incentives to follow a firm (Healy et al. 1999). 
Our study makes several important contributions to the literature. First, given that analysts are an important aspect of a firm's information environment (Bushman et al. 2004), our findings are consistent with audit committee accounting expertise having a profound impact on firms' information environment, beyond that provided by its impact on single dimensions of financial reporting, such as accrual quality. Furthermore, our results suggest that accounting experts enhance analyst following through their monitoring of accruals. Because analysts proxy for sophisticated investors and influence investors (Schipper 1991; Mikhail et al. 2007), our evidence also suggests that audit committee accounting expertise helps to enhance investor confidence in financial reporting. Since firms realize significant benefits from analyst following, ${ }^{2}$ evidence of a positive relation between analyst following and audit committee accounting expertise should be useful to firms seeking to enhance analyst coverage.

Second, we extend Abernathy et al. (2013). While Abernathy et al. (2013) attempt to assess whether accruals are the channel through which accounting expertise impacts forecast accuracy and dispersion, they perform an indirect test by including accrual quality as a control variable and find that it has a weak economic impact on results. In contrast, we perform a direct test by including the interactive effect of accounting expertise and accruals quality on analyst forecast properties and find much stronger economic significance than in Abernathy et al. (2013). Moreover, we test two other channels, audit quality and management earnings forecasts, and do not find an interactive

\footnotetext{
2 Through their coverage of a firm, analysts increase a firm's visibility among investors (Womack 1996), increase liquidity (Roulstone 2003), and reduce both the cost of equity (Gebhardt et al. 2001; Gode and Mohanram 2003; Easley and O'Hara 2004) and the cost of debt (Cheng and Subramanyam 2008). Our study offers a compelling reason for firms to consider accounting expertise when appointing members to the audit committee, even for firms that already have high quality financial reporting. As Easley and O'Hara (2004) note, companies benefit from increased analyst coverage because it leads to less information asymmetry and a corresponding decline in cost of capital. Moreover, even if analysts' role is the mere dissemination of information, the model in Easley and O'Hara (2004) still predicts a beneficial decrease in information asymmetry from increased analyst following.
} 
impact. We therefore provide comprehensive and compelling evidence about the channels through which accounting expertise impacts analyst forecast properties

Finally, our study is the first to provide evidence about the relation between accounting expertise and market liquidity. Evidence about the relation between accounting expertise and both analyst following and liquidity is related to a fundamental issue in accounting research - cost of capital - that has been investigated in other settings. See, for example, Previts et al. (1994); Chung and Jo (1996); Lang and Lundholm (1996); Healy, Hutton, and Palepu (1999); Botosan and Harris (2000); Barth, Kasznik and McNichols (2001); and Tucker (2010). Our paper therefore complements important streams of accounting literature that have assessed determinants of analyst following and market liquidity, both of which are related to cost of capital.

The remainder of the paper is organized as follows. Section 2 provides background and develops our hypotheses. Section 3 describes our sample and data. Section 4 contains the main empirical results. We investigate channels though which accounting expertise improves analyst following in Section 5. We provide supporting analyses of analyst forecast properties in Section 6. Section 7 provides capital market evidence on the impact of accounting expertise. We summarize and conclude the study in Section 8.

\section{Institutional Background, Related Literature, and Hypotheses}

\subsection{Institutional Background}

The primary role of the audit committee is to oversee the financial reporting process and ensure high-quality financial reporting. The SEC has long recommended that companies utilize audit committees (SEC 1940). Regulators now focus more on the composition of the audit committee. In 1999, in response to concerns that audit committees were not effective in their monitoring role, the New York Stock Exchange (NYSE) and the National Association of Securities Dealers 
(NASD) collaborated to form the Blue Ribbon Committee (BRC) on improving the effectiveness of corporate audit committees. The BRC recommended that audit committee composition include at least three "financial literates", at least one of whom is a "financial expert" (BRC 1999). The financial analysts' professional association, $\mathrm{AIMR},{ }^{3}$ supported the $\mathrm{BRC}$ recommendations for the composition of the audit committee, suggesting that analysts consider audit committee composition important (AIMR 1999). The U.S. stock exchanges quickly adopted the BRC's recommendations with SEC approval in late 1999.

Section 407 of SOX underscores the importance of audit committee financial expertise by requiring registrants to disclose the name of at least one member on the audit committee who is a financial expert or disclose the reason for not having such an expert. SOX recommended a narrow definition that required a direct accounting background, but left the final definition to the SEC. The SEC's initial definition of audit committee financial expertise was also narrow, and highly controversial. Among others, AIMR indicated its support for the narrow definition of financial expertise (AIMR 2002). ${ }^{4}$ In its final rule, the SEC allowed firms to use a broad definition of financial expertise that includes direct accounting work experience, but also includes financial reporting supervisory experience (e.g., CEOs) or experience analyzing or evaluating financial statements (e.g., investment bankers).

\subsection{Related Literature}

Researchers have devoted considerable effort to studying the relevance of the broad and narrow definition of financial expertise. Using the broad definition, prior research finds that firms with

\footnotetext{
${ }^{3}$ In 2004, AIMR changed its name to CFA Institute.

${ }^{4}$ However, AIMR did recommend that those with the professional designation of CFA should also be considered a financial expert (AIMR 2002).
} 
audit committee financial expertise, compared to those without it, are less likely to restate earnings (Agrawal and Chadha 2005; Abbott et al. 2004), less likely to dismiss their auditor following a going concern report (Carcello and Neal 2003), less likely to engage in earnings management (Bedard et al. 2004), more likely to update a voluntary earnings forecast (Karamanou and Vafeas 2005), and more quickly dismiss the audit firm of Arthur Andersen following the Enron scandal (Chen and Zhou 2007).

Other research examines the consequences of the narrow definition of financial expertise. Using a pre-SOX setting, Krishnan and Visvanathan (2008) find that only audit committee accounting expertise is related to more conservative accruals. Also using a pre-SOX setting, DeFond et al. (2005) find positive three-day abnormal returns around the appointment of accounting, but not non-accounting, experts to the audit committee. Our study differs from DeFond et al. (2005) in that we assess analyst response to audit committee appointments pre- and postSOX. Engel (2005) indicates that because of the significant regulatory shift post-SOX, it is not clear that results in DeFond et al. (2005) would hold in a post-SOX setting.

In the post-SOX period, Carcello et al. (2008) find that both accounting and non-accounting expertise are related to lower abnormal accruals. However, using a larger sample, Dhaliwal et al. (2010) report that audit committee accounting expertise is most strongly related to higher accrual quality when the accounting experts are independent, hold fewer other directorships, have shorter tenure, and when the audit committee also includes a member with a finance background. Dhaliwal et al. (2010) find no evidence of a similar relation between accrual quality and audit committee members with supervisory expertise.

Two prior studies also examine the association between board characteristics and analyst forecast properties, but not analyst following. In a paper somewhat related to ours, Byard et al. 
(2006) assess the relation between analyst forecast accuracy and four governance variables: (i) board independence, (ii) audit committee independence, (iii) CEO duality, and (iv) board size. Byard et al. (2006) show that analyst forecast accuracy is positively associated with board independence and board size and negatively associated with CEO duality; they find no association between analyst forecast accuracy and audit committee independence, however. Abernathy et al. (2013) show that accounting expertise on the audit committee is related to higher analyst forecast accuracy and lower analyst forecast dispersion. We extend these studies by examining the relation between accounting expertise on the audit committee and analyst following.

While analyst following and forecast accuracy are sometimes positively related, this is not always the case. Lehavey et al. (2011) show that firms with more complex disclosures have greater analyst following even though analyst forecast errors and dispersion both increase. As Lang et al. (2003) argue, although analyst forecast accuracy could improve because more analysts follow a

firm, analyst forecast accuracy could also operate independently from increased analyst following because of information gathering by other capital market intermediaries (e.g., buy-side analysts) and/or because firms disclose more information. Related to this latter point, Abernathy et al. (2013) report that higher quality accruals associated with accounting expertise help drive the relation between accounting expertise and forecast properties. It is therefore an open empirical question as to whether audit committee accounting expertise impacts analyst following.

\subsection{Hypotheses Development}

Theoretical and empirical studies, in addition to standards of professional practice, provide support for a plausible link between audit committee accounting expertise and analyst following. Bushman et al. (2004) suggest a theoretical link between corporate governance mechanisms, such as audit committee composition, and analysts. Analysts acquire private information by interacting 
with management and the board, by touring plant facilities, and by analyzing industry conditions and trends, etc. Analysts then aggregate public and private information for dissemination to investors (Bushman et al. 2004). Thus, analysts and corporate governance mechanisms are "interrelated information mechanisms" (Bushman et al. 2004, p. 210) that contribute to firms' transparency.

Empirically, Yu (2009) shows that analyst following increases with Standard \& Poor's transparency and disclosure rankings of board structure disclosures, suggesting analysts utilize information from these disclosures. Lang and Lundholm (1996) and Healy et al. (1999) show that analyst following is increasing in the quality of firm disclosures, including those in proxy statements where audit committee expertise is disclosed. Finally, Dickins et al. (2009) report survey evidence that analysts have more confidence in financial reporting from firms with audit committee accounting expertise.

Professional practice also suggests that analysts evaluate the audit committee. The Certified Financial Analyst (CFA) exam covers corporate governance best practices, including expertise of the board and its committees (Robinson and Weise 2010). ${ }^{5}$ A 1999 survey of financial analysts indicated that analysts believed that boards of directors were doing a poor job (Epstein and Palepu 1999), suggesting that analysts evaluated board level corporate governance prior to SOX. As noted above, analysts' professional association supported the BRC recommendations in 1999, implying that analysts are specifically concerned with the quality of the audit committee.

\footnotetext{
${ }^{5}$ Though Robinson and Weise (2010) indicate that the weight on corporate governance topics increased over the period $2000-2010$, some coverage of board expertise was included for the entire period.
} 
We hypothesize a positive relation between audit committee accounting expertise and analyst following. Analysts' decisions to follow a firm depend on the costs and benefits of doing so (Barth et al. 2001). We argue that audit committee accounting expertise lowers the costs of following a firm because analysts are able to rely more on public information and less on costly private information acquisition activities. This is because audit committee accounting expertise improves the quality of financial reporting (Carcello et al. 2008; Krishnan and Visvanathan 2008; and Dhaliwal et al. 2010) and higher quality corporate reporting is associated with greater analyst following (Bhushan 1989; Lang and Lundholm 1996; Healy et al. 1999; Arya and Mittendorf 2007; Yu 2009). In addition, analysts facilitate monitoring of managers, reducing insiders' information advantages and constraining management's asset-wasting behavior (Ellul and Panayides 2011; Jung et al. 2012). If so, then accounting expertise may support analysts' monitoring efforts, again reducing the cost of following the firm.

However, a competing theoretical argument suggests enhanced information from corporate reporting could reduce analysts' competitive advantage, thus decreasing incentives for private information acquisition (Lang and Lundholm 1996; Lehavy et al. 2011). If so, the decreased incentives suggest a negative relation between accounting expertise and analyst following. Despite this competing argument, we expect that the arguments supporting a positive relation between accounting expertise and analyst following will outweigh the arguments supporting a negative relation due to the deeper prior literature that finds a positive relation between enhanced corporate reporting and analyst following, and due to the positive views of analysts toward accounting expertise expressed in practice (e.g., AIMR 1999). Thus, our first hypothesis states:

H1: There is a positive relation between audit committee accounting expertise and analyst following. 
To the extent that audit committee accounting expertise is associated with an improvement in firms' information environment, we also expect greater market liquidity for these firms. We base our prediction on Healy et al. (1999), who show a positive relation between firm disclosure and market liquidity. The intuition for our second hypothesis is that audit committee accounting expertise increases firms' information environment, leading to increased investor interest in firms' stocks. Thus, our second hypothesis states:

$\mathrm{H} 2$ : There is a positive relation between audit committee accounting expertise and market liquidity.

Support for H2 would be consistent with analysts' incentives to increase coverage of firms with audit committee accounting expertise because market liquidity creates additional analyst interest in firms (Healy et al. 1999).

\section{Sample and Univariate Results}

\subsection{Sample}

We hand-collect data for audit committee expertise from firms' annual proxy statements. ${ }^{6}$ Because hand-collecting this data is non-trivial, we randomly select 500 firms across the S\&P 1500 from the intersection of I/B/E/S, Compustat, IRRC, First Call, and CRSP data sets over the years 1998-2003. This time period is important because many firms were likely changing their audit committee accounting expertise in response to SOX. For each firm, we obtain the name and business experience of each audit committee member from the background information provided on board members in the firm's proxy statements.

\footnotetext{
${ }^{6}$ We hand-collect data because databases with searchable director biographies are sparsely populated pre-SOX.
} 
We follow prior literature and partition our sample based on both accounting and other types of expertise (e.g., Krishnan and Visvanathan 2008; DeFond et al. 2005). In our primary analyses, we test accounting expertise. In sensitivity tests, we use other measures of financial expertise. Thus, we code categories of expertise as follows:

- Accounting Expertise: Individuals with current or previous experience as VP of Finance, CFO, Controller, or other principal financial or accounting officer of a publicly traded company, or as a CPA in public practice, consistent with the SEC's initial proposed definition of a financial expert (SEC 2003).

- Supervisory Expertise: Individuals with current or previous experience as a CEO or President of a publicly traded company, consistent with the SEC's final definition of financial expertise.

- Finance Expertise: Individuals with current or previous experience in investment banking, working at the SEC, loan/credit rating experience, or financial analyst experience, also consistent with final SEC rules (SEC 2003).

- Other: Individuals with experience that does not fall into any of the above categories.

Some individuals appointed to an audit committee have experience in multiple categories. To ensure that each individual is counted in only one category, we use the following ranking when coding: (i) accounting expertise, (ii) finance expertise, (iii) supervisory expertise, and (iv) other. This ranking process means, for example, that while some members with accounting expertise also have finance expertise, the finance expertise category does not include members with accounting expertise, and so on.

We obtain analyst data from the detail file in $\mathrm{I} / \mathrm{B} / \mathrm{E} / \mathrm{S}$, and data for control variables from Compustat, CRSP, and IRRC. After deleting firms with incomplete proxy filings or missing data for certain variables, our final sample consists of 2,342 firm-years and 460 unique firms, of which 267 are firms with accounting expertise (sample firms) and 193 are firms without accounting expertise on the audit committee (control firms). We winsorize all variables at the $1 \%$ and $99 \%$ levels to mitigate the impact of outliers. This initial sample is used in a number of sensitivity tests. For the main tests, we construct a panel of the 131 firms that appointed an accounting expert from 
1998-2003. In Table 1, we present the classification of industries across the 131 firms used in the main analyses, demonstrating that the sample is from a broad spectrum of industries.

\section{[Insert Table 1 here]}

\subsection{Univariate Results}

Panel A of Table 2 provides descriptive statistics for the variables used in the regression analyses (for the 786 firm-years included in panel A). The mean analyst following is about 6. Panel B of Table 2 provides descriptive statistics for the variables by pre- and post-appointment of an audit committee accounting expert. This panel shows a mean increase of about one analyst between the pre- and post-appointment periods, consistent with H1. This panel also shows a significant increase in trading volume, consistent with $\mathrm{H} 2$.

\section{[Insert Table 2 here]}

Panel C of Table 2 reports the Pearson correlations between the variables used in the regression analyses. There is a positive and significant correlation between analyst following and the appointment of an audit committee accounting expert, providing univariate evidence consistent with H1. There is also a positive and significant correlation between trading volume and the appointment of an audit committee accounting expert, consistent with $\mathrm{H} 2$. While most of the variables are correlated at fairly low levels, we nevertheless perform formal tests for collinearity in our regression analyses. ${ }^{7}$

\footnotetext{
${ }^{7}$ The largest VIF for any variable is 3.7, indicating that collinearity does not appear to affect the regression results.
} 


\section{Empirical Design and Multivariate Regression Results}

\subsection{Empirical Design}

Our first dependent variable of interest is analyst following. We use panel data for the sample of firms that appoint accounting experts to the audit committee in order to examine the impact of these appointments on changes in analyst following. An important issue with this approach is the time over which to expect the change in analyst behavior. In other words, is there an immediate effect, or does it take time for the new audit committee member to have an impact? It is reasonable to assume that a new audit committee member requires time to understand the intricacies of his/her firm's business and thus be in a position to influence a firm's disclosures. In the spirit of Lang et al. (2003), we therefore examine whether analyst following changes from three years prior to the appointment of an accounting expert on the audit committee to three years afterward. We use a time-series specification to avoid self-selection bias. To execute our test, we use the following model:

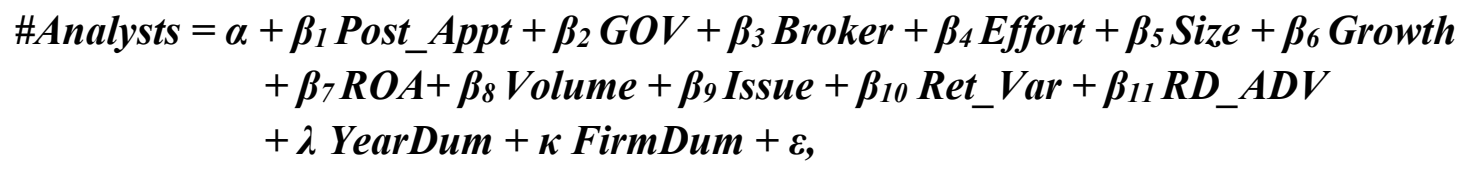

where \#Analysts is the number of analysts (adjusted for the median of analyst following in the firm's industry $)^{8}$ with annual earnings forecasts in the month closest to, but within a preceding three-month window of, the annual earnings announcement (Barth et al. 2001). ${ }^{9}$ Our variable of

\footnotetext{
${ }^{8}$ We industry-adjust analyst following to control for the increasing trend in analyst following. Untabulated statistics indicate that mean analyst following increased from 3.3 to 4.3 for the entire sample of IBES firms over our sample period.

${ }^{9}$ For sensitivity, we also use each firm as its own control and obtain similar results to those reported (untabulated).
} 
interest, Post_Appt, is equal to one for the three years following the accounting expert appointment and zero for the three years prior to the appointment.

To control for the effect of other governance mechanisms, we use the composite variable, GOV. Following DeFond et al. (2005), we aggregate board size, board independence, audit committee size, audit committee independence, G-Index (Gompers et al. 2003), and institutional ownership. ${ }^{10}$ Each component equals one if it exceeds the sample median and zero otherwise. We sum the components and create a dichotomous variable, GOV, equal to one if the sum exceeds the median of the summed values of all observations.

Because of the mechanical relation between the size of the brokerage firm that covers a firm and the number of analysts that cover a firm, we include the variable, Broker, the average number of analysts in the brokerage houses that cover a firm (Barth et al. 2001). Barth et al. (2001) also report that firms requiring more analyst effort have lower analyst following, so we include the negative of the average number of firms covered by the firm's analysts (Effort).

We include controls for firm size (Size), measured as the log of market capitalization at the end of the fiscal year, and growth (Growth), measured as the average sales growth over the five prior years (Bhushan 1989; O'Brien and Bhushan 1990; Lang and Lundholm 1996). Following Ali et al. (2007), we include a control for firm profitability, ROA, measured as net income divided by total assets.

Following Barth et al. (2001), we control for analysts' incentives to follow a firm and include the variables Volume and Issue. Volume is a firm's trading volume and reflects potential trading commissions to brokerage houses. Because analysts are compensated for trade in stocks that they

\footnotetext{
${ }^{10}$ Please refer to DeFond et al. (2005, pp. 169-170) for details on each of these components.
} 
cover (Irvine 2000), analyst following is likely to increase with trading volume. Also, firms that issue public securities generate investment banking fees that brokerage houses value. We measure Issue as the dollar magnitude of issuances of either public debt or equity in the current or prior year. We include a control for return variance, Ret_Var, because firms with higher return variance are likely to have higher expected trading profits, leading to increased analyst following (Bhushan 1989). We measure Ret_Var using daily stock return variance estimated over the 200 days prior to the end of the fiscal year.

Firms with more intangible assets are likely to have less informative financial statements, thus providing incentives to analysts with superior skills to generate trading profits for their clients (Barth et al. 2001). We use the variable $R D \_A D V$, the sum of research and development expenses and advertising expenses divided by sales, to control for this effect. Finally, we control for year (YearDum) and firm (FirmDum) fixed effects.

\subsection{Main Regression Results}

We use a Poisson model to estimate equation (1) and report results after adjusting for firm clusters. ${ }^{11}$ Consistent with H1, results in Table 3 show a positive and significant coefficient of $0.3706(\mathrm{p}<0.01)$ on Post_Appt, implying that analyst following increases following the appointment of an accounting expert to the audit committee. ${ }^{12}$ This result is consistent with the univariate results in panel $\mathrm{B}$ of Table 2. We next assess the economic significance of this result. Because a Poisson regression coefficient represents the change in response (natural logged response) corresponding to a one unit change in the corresponding predictor, we need to

\footnotetext{
${ }^{11}$ Inferences are unchanged using an OLS regression with the natural log of the number of analysts (untabulated) as the dependent variable.

${ }^{12} \mathrm{We}$ also use a TOBIT model to control for the count data nature of \#Analysts (Rock et al. 2001), leaving inferences unaffected (untabulated).
} 
exponentiate results to obtain the percentage change in analyst following. Doing so yields a value of 1.45 (i.e., $\exp (0.3706)=1.45)$. This result implies that firms appointing an accounting expert to their audit committees experience a $45 \%$ increase in analyst coverage. Given that median analyst coverage is 4.5 , the addition of an audit committee accounting expert results in about two additional analysts for a typical firm. Thus, our results are economically significant. Results for the coefficients on the control variables are generally consistent with prior research.

\section{[Insert Table 3 here]}

\subsection{Robustness Tests}

We next perform a battery of untabulated robustness tests, the results of which do not affect inferences from our main results reported in Table 3.

- As we argue above, it likely takes some time for a new audit committee member to become knowledgeable enough about a firm's operations to influence the firm's financial reporting. We nevertheless estimate our main regression model over the alternative periods of one year before and after and two years before and after the appointment of an accounting expert. As we conjectured, the magnitude of the coefficient on our variable of interest increases in size as the analysis period lengthens. The coefficient on our variable of interest is $0.0905(\mathrm{p}=0.07)$ for years -1 to +1 and $0.1808(\mathrm{p}=0.00)$ for years -2 to +2 . Recall that the coefficient on our variable of interest in Table 3 is $0.3706(\mathrm{p}=0.00)$.

- Though our changes analysis reported in Table 3 incorporates controls for other variables expected to impact analyst following, a limitation of this approach is that other events potentially confound our results. As another check on the robustness of the results, we use the full sample of 460 (2342) firms (firm-years) and estimate the results using a pooled cross-sectional regression. We find results consistent with those reported.

- Given that the SOX definition of audit committee financial expertise encompasses more than accounting expertise, we also assess the effects of non-accounting financial expertise (i.e., supervisory and finance) on analyst following. We include in Model (1) firms that appoint non-accounting financial experts during our sample period and find that nonaccounting expertise is not significant, while the coefficient on the accounting expertise variable remains significant and consistent with the main results in Table 3.

- Dhaliwal et al. (2010) find that the combination of accounting expertise and finance expertise on the audit committee is associated with improved accrual quality. In an additional test, we find that accounting expertise, alone or in combination with finance and/or supervisory expertise, is positively related to analyst following, while neither finance nor supervisory expertise alone is significant.

- Reg FD was passed on October 23, 2000 and could impact analyst following because of restrictions on private communications between firms and analysts. We re-estimate model 
(1) and include an interaction of Post_Appt and a dummy variable equal to one for the post Reg-FD period (i.e., 2000-2003). Results indicate that the coefficient on the interaction is not significant, implying that Reg FD does not affect results.

- We re-estimate Model (1) using an alternative measure of governance strength. We follow Carcello et al. (2008) and estimate the alternative measure using the following variables: Board size $=1$ if the firm's board size is between six and nine members, else 0; Board expertise $=1$ if the percentage of independent directors who hold seats on other firms' boards is greater than the sample median, else 0 ; Relative audit committee power $=1$ if the proportion of the firm's audit committee size to its board size is greater than the sample median, else 0; Audit committee independence $=1$ if the audit committee is 100 percent independent, else 0; Audit committee meetings $=1$ if the number of audit committee meetings is greater than or equal to five, else 0 ; Institutional ownership $=1$ if the firm's percentage of institutional ownership is greater than the sample median, else 0 . As we did earlier, we sum the governance variables and create a dichotomous variable for governance strength equal to one if the sum exceeds the median of the summed values of all observations. Using this alternative governance measure, we obtain results similar to those reported.

- It is reasonable to assume that SOX increased pressure to add accounting expertise, which could also change analysts' view of the audit committee. Thus, it is possible that the relation between audit committee accounting expertise and analyst following differs between the pre- and post-SOX regimes. To test our conjecture, we re-estimate equation (1) after adding an interaction between Post_Appt and a dummy variable equal to one for the years after SOX (i.e., 2002-2003). We find that neither the coefficient on SOX nor the interaction term with SOX is significant.

\section{Potential Channels through which Accounting Expertise Impacts Analyst Following}

We next provide an exploratory analysis of channels through which accounting expertise might impact analyst following. Guided by prior research, we conjecture that accounting experts could influence analyst following through their influence on audit quality proxied by Big 4 auditors (Big4), management earnings forecasts (MEF), and/or accrual quality (AQ). The positive relation between accounting expertise and analyst following that we find could be attributed to the effect of the audit committee on these three channels.

We investigate audit quality because Behn et al. (2008) show that Big 4 auditors improve the properties of analysts' forecasts. Accounting experts could impact analyst following either by influencing the appointment of Big 4 auditors or by facilitating the effectiveness of existing Big 4 auditors. We measure Big4 as an indicator variable equal to one for firms that use a Big4 auditor. 
We investigate management earnings forecasts (MEF) because prior studies find that MEFs are an important channel through which managers can provide firm-specific information to investors (e.g., Coller and Yohn 1997; Lennox and Park 2006). Again, accounting experts could impact analyst following by influencing management disclosure of forward-looking information. We obtain MEFs from the First Call Historical Database's Company Issued Guidance file and use the number of annual MEFs issued during the fiscal year.

Finally, we investigate accrual quality because prior research finds a positive relation between accounting expertise on the audit committee and earnings quality. Additionally, Yu (2008) finds that analyst following and abnormal accruals are negatively related. We argue that accounting experts can use their skill to improve accrual quality and thus positively influence analyst following. We test the accrual quality channel using the absolute value of abnormal accruals (AQ) multiplied by -1 . Thus, higher values of AQ imply higher accrual quality. We follow Kothari et al. (2005) and compute unsigned abnormal accruals using a modified version of the Jones (1991) model with performance-matching based on return on assets.

We execute our channel analysis by employing the same basic regression model from Table 3 . We separately add to the baseline regression proxies for each of the three channels and also combine all three channels in one regression. We utilize interaction terms between each channel and our indicator variable for the appointment of an accounting expert. These interaction terms allow us to directly assess the impact of each channel on analyst following. We tabulate results of our channel analysis in Table 4 using five models. Model (1) is the baseline regression and provides key results reported in Table 3. Model (2) shows results for Big4, Model (3) shows results for MEF, Model (4) shows results for AQ, and Model (5) shows results including all three channels. 
Results in Table 4 show no impact of a Big 4 auditor (Model 2) or MEF (Model 3) on analyst following either before or after the appointment of an accounting expert. In contrast to results for Big4 and MEF, we report in Models (4) and (5) that accrual quality has a positive and significant impact on analyst following after the appointment of an accounting expert. ${ }^{13}$ These results are consistent with analysts recognizing that accounting experts enhanced their firms' financial reporting through higher accrual quality.

\section{[Insert Table 4 here]}

\section{Information Quality of Analysts' Forecasts}

Similar to Abernathy et al. (2013), we also examine the relation between the appointment of an accounting expert and analyst forecast properties. A finding that analysts' information quality is higher in the presence of audit committee accounting expertise would support the beneficial effects of audit committee accounting expertise on the information environment. Following prior research, we assess the relation between audit committee accounting expertise and (i) forecast error and (ii) forecast dispersion as proxies of analysts' information quality.

We execute our tests of analyst forecast properties using Model (1), except that we substitute analyst forecast error and analyst forecast dispersion for analyst following and include analyst following as a control variable. We measure analyst forecast error as the absolute value of the median ${ }^{14}$ forecast of annual earnings per share (EPS) less actual EPS scaled by stock price. We measure forecast error at the same time as analyst following. We measure forecast dispersion as the standard deviation of analysts' annual earnings forecast scaled by stock price (again, measured

\footnotetext{
${ }^{13}$ The tenor of these results is similar over alternative analysis periods of -1 to +1 and -2 to +2 years relative to the appointment of an accounting expert to the audit committee (untabulated).

${ }^{14}$ Inferences are unchanged using the mean forecast (untabulated).
} 
at the same time as analyst following). Because we require at least three analysts to calculate dispersion, fewer observations are available for dispersion than for analyst following and forecast accuracy.

In Table 5, we report results for tests of analyst forecast properties. We report a negative and significant coefficient of -0.0006 (-0.0006) on Post_Appt for forecast error (forecast dispersion). ${ }^{15}$ These findings are consistent with those in Abernathy et al. (2013) and the argument that audit committee accounting expertise improves information quality and reduces the need for analysts to obtain costly private information. ${ }^{16}$ The coefficients on Effort, Size, ROA, and Volume are significant and generally consistent with prior research.

\section{[Insert Table 5 here]}

\subsection{Analysis of Channels through which Accounting Expertise impacts Forecast Properties}

Although results in Table 5 largely confirm those in Abernathy et al. (2013), missing from Abernathy et al. (2013) is a direct test of the channel through which accounting expertise enhances analyst forecast properties. Abernathy et al. (2013) perform an indirect test by adding to their crosssectional regression a variable intended to capture accrual quality. We extend Abernathy et al. (2013) by performing a more direct test of the channels through which accounting experts can potentially influence analyst forecast properties. Additionally, our tests are more comprehensive in that we employ three potential channels, while Abernathy et al. (2013) only employ one channel.

\footnotetext{
${ }^{15}$ In untabulated tests, we also find that the tenor of results is similar over alternative analysis periods of -1 to +1 and -2 to +2 , similar to results for analyst following.

${ }^{16}$ Abernathy et al. (2013) measures forecast accuracy as negative forecast error and thus show a positive coefficient on increased audit committee expertise.
} 
We follow the method used in Table 4 to assess the channels through which accounting expertise impacts analyst forecast properties. We present the related results in Table 6 . Results for forecast error are reported in panel A. Model (1) presents baseline results from Table 5. Model (2) indicates that while Big 4 firms reduce forecast errors, there is no difference in the effect of a Big 4 firm on forecast error before or after the appointment of an accounting expert. Model (3) shows no impact of management earnings forecasts on forecast errors in either the pre- or postappointment periods. Models (4) and (5) show that accrual quality significantly reduces forecast error following the appointment of an accounting expert, consistent with results reported in Table 4. In panel B, we report results for forecast dispersion that are similar to those for forecast error, except that accrual quality has no impact on forecast dispersion in the period prior to the appointment of an accounting expert to the audit committee.

Note that Abernathy et al. (2013) report very small changes in the magnitude of the coefficient on their variable for accounting expertise when they add accrual quality to their regression. By contrast, the coefficients on our interaction term of accounting expertise and accrual quality show large and significant improvements in analyst forecast properties due to accounting expertise. Overall, results in Table 6 are consistent with those in Table 4 and demonstrate a direct link between accounting expertise and analyst forecast properties through enhanced accrual quality. ${ }^{17}$

\section{[Insert Table 6 here]}

\subsection{Simultaneous Equation Analyses of Analyst Following and Analyst Forecast Properties}

We recognize that analyst following and analyst forecast characteristics are interrelated, though not in a mutually exclusive or redundant way (Lang et al. 2003). Alford and Berger (1999)

\footnotetext{
${ }^{17}$ The tenor of results in Table 6 holds for alternative analysis periods of -1 to +1 and -2 to +2 (untabulated).
} 
indicate that analyst following and forecast accuracy are simultaneously determined. We consequently estimate a system of equations similar to that in Alford and Berger (1999). In the first model, we regress analyst following on forecast accuracy, the accounting expertise indicator variable, and the same set of control variables from Model (1), except that we drop Volume. In the second model, we regress forecast accuracy on analyst following, accounting expertise, and the same set of controls from Model (1), except that we drop $R D \_A D V$. For completeness, we also estimate a similar system of equations to control for the simultaneity of analyst following and forecast dispersion. Untabulated results indicate that inferences for accounting expertise are consistent with those reported in Table 3 . These results suggest that simultaneity is not an issue in our setting.

\section{Capital Market Consequences of Audit Committee Accounting Expertise}

While our prior analyses attempt to control for known factors related to analysts' decisions and also control for firm fixed effects, results in Brown et al. (2015) suggest that analysts' incentives to follow firms are not clear. In H2, we seek to provide more direct evidence of a capital market effect from audit committee accounting expertise by assessing the relation between audit committee accounting expertise and both trading volume and Liu's (2006) measure of liquidity risk.

Trading volume is a widely used measure related to analysts' incentives to cover a firm (Beyer and Guttman 2011). We measure trading volume as the log of the number of shares (in millions) traded during the fiscal year. In panel A of Table 7, we show a positive and significant coefficient on audit committee accounting expertise. Our finding that firms with audit committee accounting expertise generate more investor interest is consistent with theory that suggests trading volume increases in the precision of public information (Kim and Verrecchia 1994). This result is also 
consistent with the increase in analyst following, in that higher trading volume generates greater potential trading commissions to brokerage houses. However, theory also suggests trading volume increases in investor disagreement, as proxied by forecast dispersion (Ajinkya et al. 1991). Thus, we also control for forecast dispersion in our trading volume model and find forecast dispersion also increases trading volume. Since audit committee accounting expertise reduces forecast dispersion, our results suggest that both theoretical effects are evident and that the net effect of audit committee accounting expertise on trading volume is positive, consistent with $\mathrm{H} 2$.

\section{[Insert Table 7 here]}

As an additional test of the market impact of accounting expertise, we employ the measure of liquidity risk from Liu (2006) and include in panel B of Table 7 analyses of the relation between liquidity risk and audit committee accounting expertise. Liu (2006) develops a comprehensive measure of liquidity risk that captures the multi-dimensional nature of liquidity, including trading volume turnover. Liu (2006) finds that his measure of liquidity risk is positively related to asset returns. In our setting, we expect that if accounting expertise reduces information asymmetry and thus lowers liquidity risk, then the coefficient on accounting expertise should be negative and significant.

Following Liu (2006), we measure liquidity risk as the standardized turnover-adjusted number of zero daily trading volumes over the prior twelve months. Consistent with our expectation, results in panel $\mathrm{B}$ of Table 7 show negative and significant coefficients on audit committee accounting expertise, implying that the addition of audit committee accounting expertise is related to lower liquidity risk, which has been shown to be related to a lower cost of capital (Liu 2006). This result is consistent with the trading volume results in panel A of Table 7. Taken together, results for trading volume and liquidity risk imply that investors positively value the addition of 
accounting expertise to the audit committee, which provides analysts with greater incentives to follow these firms. Showing that accounting expertise provides economic benefits beyond increased analyst following and analyst forecast properties also extends the broader literature on the economic benefits associated with audit committee accounting expertise.

\section{Summary and Conclusions}

We examine the relation between audit committee accounting expertise and analyst following. We find that analyst following is higher after firms increase audit committee accounting expertise. This result is consistent with the notion that audit committee accounting expertise reduces analysts' costs to follow a firm. Our main results are robust to a host of controls known to be related to analyst following. In robustness tests, we find that our main inferences are unaffected by alternative analysis periods, pooled cross-sectional regressions, other types of audit committee financial expertise, the pre- and post-Reg FD periods, an alternative measure of governance strength, the pre- and post-SOX periods, and simultaneity. Importantly, we demonstrate that accounting experts improve analyst following through the channel of accrual quality. We similarly show that accounting experts are associated with lower forecast errors and forecast dispersion, also through the channel of accrual quality. Finally, we provide evidence that audit committee accounting expertise is related to higher trading volume and lower liquidity risk, suggesting that accounting expertise provides capital market benefits, thereby supporting incentives for increased analyst following.

We make several important contributions to the literature. Our study is the first to document an empirical link between audit committee expertise and analyst following. This is important because analysts affect firms' information environment, which is a key determinant of resource allocation and economic growth (Bushman et al. 2004). Our finding that the impact of audit 
committee accounting expertise on analyst following flows from the channel of accrual quality deepens our understanding of the interrelations between audit committee accounting expertise and financial reporting in enhancing the information environment. Our study also provides evidence that firms with audit committee accounting expertise enjoy higher trading volume and lower liquidity risk, supporting analyst incentives to follow firms and implying that these firms enjoy additional capital market benefits beyond increased analyst following and enhanced forecast properties. Our findings should therefore be useful to firms seeking to enhance market liquidity and analyst following.

Our findings also contribute to the ongoing debate regarding the efficacy of regulatory and legislative efforts that seek to improve the financial expertise of audit committees. Because analysts are a proxy for sophisticated investors and influence investors (Schipper 1991), our results also support the importance of audit committee accounting expertise according to the SEC's original narrow definition of financial expertise. 


\section{References}

Abbott, L.J., S. Parker, and G.F. Peters. 2004. "Audit Committee Characteristics and Restatements." Auditing: A Journal of Practice \& Theory 23 (1): 69-87.

Abernathy, J.L., D. Herrmann, T. Kang, and G.V. Krishnan. 2013. Audit committee financial expertise and properties of analyst earnings forecasts. Advances in Accounting 29: 1-11.

Agrawal, A. and S. Chadha. 2005. "Corporate Governance and Accounting Scandals." Journal of Law and Economics 48 (2): 371-406.

Ajinkya, B., R. Atiase, and M. J. Gift. 1991. Volume of Trading and the Dispersion in Financial Analysts' Earnings Forecasts. The Accounting Review 66: 389-401.

Alford, A.W. and P.G. Berger. 1999. "A Simultaneous Equations Analysis of Forecast Accuracy, Analyst Following, and Trading Volume." Journal of Accounting, Auditing, and Finance 14: 219-240.

Ali, A., T. Chen, and S. Radhakrishnan. 2007. "Corporate Disclosures by Family Firms." Journal of Accounting and Economics 44: 238-286.

Arya, A. and B. Mittendorf. 2007. "The Interaction Among Disclosure, Competition Between Firms, and Analyst Following." Journal of Accounting and Economics 43: 321-339.

Association for Investment Management and Research (AIMR). 1999. Comment letter to Securities and Exchange Commission's proposed rules and rule amendments related to corporate audit committee disclosure, November 29.

Association for Investment Management and Research (AIMR). 2002. Comment letter to Securities and Exchange Commission's proposed implementation of the disclosure required by sections 404, 406 and 407 of the Sarbanes-Oxley Act, December 12.

Barth, M., R. Kasznik, and M. McNichols. 2001. "Analyst Coverage and Intangible Assets." Journal of Accounting Research 39: 1-34.

Bedard, J., S.M. Chtourou, and L. Courteau. 2004. "The Effect of Audit Committee Expertise, Independence, and Activity on Aggressive Earnings Management." Auditing: A Journal of Practice \& Theory 23 (2): 13-35.

Behn, B., J-H Choi, and T. Kang. 2008. "Audit Quality and Properties of Analyst Earnings Forecasts." The Accounting Review 83: 327-349.

Beyer, A. and I. Guttman. 2011. "The Effect of Trading Volume on Analysts' Forecast Bias." The Accounting Review 86: 451-481.

Bhushan, R. 1989. "Firm Characteristics and Analyst Following." Journal of Accounting and Economics 11: 255-274. 
Blue Ribbon Committee on Improving the Effectiveness of Corporate Audit Committees (BRC). 1999. Report and Recommendations of the Blue Ribbon Committee on Improving the Effectiveness of Corporate Audit Committees. New York Stock Exchange and National Association of Securities Dealers (www.nyse.com).

Botosan, C. A., \& Harris, M. S. (2000). Motivations for a change in disclosure frequency and its consequences: An examination of voluntary quarterly segment disclosures. Journal of Accounting Research: 329-353.

Brown, L. D., A. C, Call, M. B. Clement, and N. Y. Sharp. 2015. Inside the "Black Box" of sellside financial analysts. Journal of Accounting Research 53: 1-47.

Brown, L. D., A. C, Call, M. B. Clement, and N. Y. Sharp. 2014. Skin in the game: The inputs and incentives that shape buy-side analysts' stock recommendations. Working paper, The University of Texas at Austin.

Bushman, R., J. Piotroski, and A. Smith. 2004. "What Determines Corporate Transparency?" Journal of Accounting Research 42: 207-252.

Byard, D., Y. Li, and J. Weintrop. 2006. "Corporate Governance and the Quality of Financial Analysts' Information.” Journal of Accounting and Public Policy 25: 609-625.

Carcello, J.V., C.W. Hollingsworth, A. Klein, and T.L. Neal. 2008. "Audit Committee Financial Expertise, Competing Corporate Governance Mechanisms, and Earnings Management." Working paper, University of Tennessee.

Carcello, J.V. and T.L. Neal. 2003. "Audit Committee Characteristics and Auditor Dismissals Following "New" Going-concern Reports." The Accounting Review 78 (1): 95-117.

CFA Institute. 2005. Standards of Practice Handbook Ninth Edition. Charlottesville, VA: CFA Institute.

Chen, K.Y. and J. Zhou. 2007. "Audit Committee, Board Characteristics, and Auditor Switch Decisions by Andersen's Clients.” Contemporary Accounting Research 24 (4): 10851117.

Cheng, M. and K.R. Subramanyam. 2008. "Analyst Following and Credit Ratings." Contemporary Accounting Research 25 (4): 1007-1043.

Chung, K. H., \& Jo, H. (1996). The impact of security analysts' monitoring and marketing functions on the market value of firms. Journal of Financial and Quantitative Analysis, 31(4): 493-512.

Coller, M. and T.L. Yohn. 1997. "Management Forecasts and Information Asymmetry: An Examination of Bid-Ask Spreads.” Journal of Accounting Research 35: 181-191.

DeFond, M.L., R.N. Hann, and X. Hu. 2005. "Does the Market Value Financial Expertise on Audit Committees of Boards of Directors?” Journal of Accounting Research 45 (2): 153193. 
Dhaliwal, D., V. Naiker, and F. Navissi. 2010. "The Association Between Accruals Quality and the Characteristics of Accounting Experts and Mix of Expertise on Audit Committees." Contemporary Accounting Research 27 (3): 787-827.

Dickins, D., W. Hillison, and S. Platau. 2009. "Do Financial Statement Users Care About Differences in Board Members' Source of Financial Expertise? Views of Financial Analysts." Journal of Applied Business and Economics 9 (2): 21-37.

Easley, D. and M. O'Hara. 2004. "Information and the Cost of Capital." Journal of Finance 59: 1029-1583.

Ellul, A. and M. A. Panayides. 2011. "Do Financial Analysts Restrain Insiders' Informational Advantage?” Working paper, Indiana University.

Engel, E. 2005. "Discussion of Does the Market Value Financial Expertise on Audit Committees of Boards of Directors." Journal of Accounting Research 43 (2): 195-204.

Epstein, M.J. and K.G. Palepu. 1999. “What Financial Analysts Want.” Strategic Finance 80 (10): 48-52.

Gebhardt, W.R., C.M.C. Lee, and B. Swaminathan. 2001. "Toward an Implied Cost of Capital." Journal of Accounting Research 39 (1): 135-176.

Gode, D. and P. Mohanram. 2003. "Inferring the Cost of Capital Using the Ohlson-Juettner Model." Review of Accounting Studies 8 (3): 399-431.

Gompers, P., J. Ishii, and A. Metrick. 2003. "Corporate Governance and Equity Prices." Quarterly Journal of Economics 118: 107-155.

Healy, P.M., A.P. Hutton, and K.G. Palepu. 1999. "Stock Performance and Intermediation Changes Surrounding Sustained Increases in Disclosures." Contemporary Accounting Research 16 (3): 485-520.

Hermalin, B.E. and M.S. Weisbach. 2003. "Boards of Directors as an Endogenously Determined Institution: A Survey of the Economic Literature." Economic Policy Review - Federal Reserve Bank of New York 9 (1): 7-26.

Irvine, P. 2000. "Do Analysts Generate Trade for Their Firms? Evidence from the Toronto Stock Exchange." Journal of Accounting and Economics 30: 209-226.

Jones, J. 1991. "Earnings Management During Import Relief Investigations." Journal of Accounting Research 29: 193-228.

Jung, B., K.J. Sun, and Y.S. Yang. 2012. "Do Financial Analysts Add Value by Facilitating More Effective Monitoring of Firms' Activities? Journal of Accounting, Auditing \& Finance 27 (1): 61-99. 
Karamanou, I. and N. Vafeas. 2005. "The Association Between Corporate Boards, Audit Committees, and Management Earnings Forecasts: An Empirical Analysis.” Journal of Accounting Research 43 (3): 453-486.

Kim, O., and R. Verrecchia. 1994. Market liquidity and volume around earnings announcements. Journal of Accounting and Economics 17: 41-67.

Klein, A. 1998. "Firm Performance and Board Committee Structure." Journal of Law and Economics 41 (1): 275-304.

Kothari, S.P., A.J. Leone, and C.E. Wasley. 2005. "Performance Matched Discretionary Accrual Measures." Journal of Accounting and Economics 39: 163-197.

Krishnan, G.V. and G. Visvanathan. 2008. "Does the SOX Definition of an Accounting Expert Matter? The Association Between Audit Committee Directors' Accounting Expertise and Accounting Conservatism." Contemporary Accounting Research 25 (3): 827-857.

Lang, M.H., K.V. Lins, and D.P. Miller. 2003. “ADRs, Analysts, and Accuracy: Does Crosslisting in the U.S. Improve a Firm's Information Environment and Increase Market Value?" Journal of Accounting Research 41: 317-345.

Lang, M.H. and R.J. Lundholm. 1996. "Corporate Disclosure Policy and Analyst Behavior.” The Accounting Review 71 (4): 467-492.

Lehavy, R., F. Li, and K. Merkley. 2011. "The Effect of Annual Report Readability on Analyst Following and the Properties of Their Earnings Forecasts." The Accounting Review 86 (3): 1087-1115.

Lennox, C.S. and C.W. Park. 2006. "The Informativeness of Earnings and Management's Issuance of Earnings Forecasts.” Journal of Accounting and Economics 42: 439-458.

Liu, W. 2006. A liquidity-augmented capital asset pricing model. Journal of Financial Economics 82: 631-671.

Mikhail, M.B., B.R. Walther, and R.H. Willis. 2007. "When Security Analysts Talk, Who Listens?" The Accounting Review 82 (5): 1227-1253.

O'Brien, P. and R. Bhushan. 1990. "Analyst Following and Institutional Ownership.” Journal of Accounting Research 28: 55-82.

Previts, G. J., Bricker, R. J., Robinson, T. R., \& Young, S. J. (1994). A content analysis of sellside financial analyst company reports. Accounting Horizons 8(2): 55-70. 
Rajgopal, S., T. Shevlin, and M. Venkatachalam. 2003. "Does the Stock Market Fully Appreciate the Implications of Leading Indicators for Future Earnings? Evidence From Order Backlog." Review of Accounting Studies 8 (4): 461-492.

Robinson, T.R. and C.B. Wiese. 2010. The CFA Program Candidate Body of Knowledge: The Past Decade 2000-2010. Charlottesville, VA: CFA Institute.

Rock, S., S. Sedo, M. Willenborg. 2001. "Analyst Following and Count-Data Econometrics." Journal of Accounting and Economics 30: 351-373.

Roulstone, D.T. 2003. "Analyst Following and Market Liquidity." Contemporary Accounting Research 20 (3): 551-578.

Schipper, K. 1991. “Commentary on Analysts' Forecasts." Accounting Horizons 5 (4): 105-121.

Securities and Exchange Commission (SEC). 1940. In the Matter of McKesson \& Robbins, Inc. Accounting Series Release No. 19. Washington, D.C.: Government Printing Office.

Securities and Exchange Commission (SEC). 2003. Disclosure required by Sections 406 and 407 of the Sarbanes-Oxley Act of 2002, Final Rule S7-40-02. Washington, D.C.: Government Printing Office.

Tucker, J. W. (2010). Is silence golden? Earnings warnings and subsequent changes in analyst following. Journal of Accounting, Auditing and Finance 25(3): 431- 456.

Womack, K.L. 1996. “Do Brokerage Analysts' Recommendations Have Investment Value?” The Journal of Finance 51 (1): 137-167.

Yu, F. 2008. "Analyst Coverage and Earnings Management." Journal of Financial Economics 88: 245-271.

Yu, M. 2009. "Analyst Forecast Properties, Analyst Following and Governance Disclosures: A Global Perspective." Journal of International Accounting, Auditing and Taxation 19:115. 


\section{Table 1}

Industry Classification of Sample Firms

\begin{tabular}{llrr}
\hline Industry & 2-Digit SIC Code & $\mathrm{n}$ & \% Total \\
\hline Oil and Gas & 13 & 4 & 3.05 \\
Food Products & 20 & 5 & 3.82 \\
Paper and Paper Products & $24-27$ & 8 & 6.11 \\
Chemical Products & 28 & 18 & 13.74 \\
Manufacturing & $30-34$ & 7 & 5.34 \\
Computer Equipment and Services & 35,73 & 14 & 10.69 \\
Electronic Equipment & 36 & 9 & 6.87 \\
Transportation & $37,39,40,42,44,45$ & 10 & 7.63 \\
Scientific Instruments & 38 & 13 & 9.92 \\
Durable Goods & 50 & 4 & 3.05 \\
Retail & $53-57,59$ & 7 & 5.34 \\
Eating and Drinking Establishments & 58 & 0 & 0.00 \\
Entertainment Services & 70,79 & 1 & 0.76 \\
Health & 80 & 2 & 1.53 \\
Professional Services & 87 & 0 & 0.00 \\
All Others & All Others & 29 & 22.14 \\
Total & & 131 & 100.00 \\
\hline
\end{tabular}


Table 2

\section{Descriptive Statistics and Correlations of Variables used in Regression Analyses}

\begin{tabular}{lccccc} 
Panel A: Descriptive Statistics $(n=786)$ & \\
\hline Variable & Mean & Std. Dev. & Q1 & Median & Q3 \\
\hline \#Analysts & 5.911 & 6.489 & 1 & 4.500 & 9 \\
Post_Appt & 0.500 & 0.500 & 0 & 0.500 & 1 \\
GOV & 0.383 & 0.486 & 0 & 0 & 1 \\
Big4 & 0.985 & 0.123 & 1.000 & 1.000 & 1.000 \\
MEF & 1.910 & 2.604 & 0.000 & 1.000 & 4.000 \\
AQ & -0.057 & 0.058 & -0.073 & -0.042 & -0.019 \\
Broker & 46.239 & 25.161 & 22.333 & 50.746 & 64.455 \\
Effort & -9.140 & 5.570 & -12.125 & -8.850 & -5.750 \\
Size & 8.117 & 1.332 & 7.163 & 8.031 & 9.019 \\
Growth & 0.108 & 0.217 & 0.001 & 0.077 & 0.177 \\
ROA & 0.052 & 0.067 & 0.023 & 0.051 & 0.087 \\
Volume & 363.896 & 660.549 & 57.133 & 131.809 & 351.030 \\
Issue & 92.277 & 223.411 & 4.315 & 17.002 & 58.051 \\
Ret_Var & 0.001 & 0.001 & 0.000 & 0.001 & 0.001 \\
RD_Adv & 0.038 & 0.052 & 0.000 & 0.016 & 0.052 \\
\hline
\end{tabular}

\section{Variable Definitions:}

\#Analysts is the number of analysts with annual earnings forecasts in the month closest to, but preceding, the annual earnings announcement adjusted by subtracting the industry median. Post_Appt is a dummy variable equal to one for the three years following the appointment of an accounting expert and zero for the three years prior to the appointment of an audit committee accounting expert. GOV is an aggregate governance measure that is comprised of the following components: board size, board independence, audit committee size, audit committee independence, G-Index (Gompers, Ishii, and Metrick 2003), and institutional ownership. Please refer to DeFond et al. (2005, pp. 169-170) for details of each of these components. Each component equals one if it exceeds the sample median and zero otherwise. We sum the components and create a dichotomous variable equal to one if the sum exceeds the median of the summed values of all observations. Big4 is a dummy variable equal to one for firms with a Big 4 auditor. MEF is the number of annual management earnings forecasts in fiscal year t. AQ is total abnormal accruals multiplied by -1; we follow Kothari, Leone and Wasley (2005) and compute unsigned abnormal accruals using a modified version of the Jones (1991) model with performance matching based on return on assets. Broker is the average number of analysts employed by the brokerage houses of the firm's analysts. Effort is the negative of the average number of firms covered by the firm's analysts. Size is the natural log of market capitalization (in \$million). Growth is the firm's prior five year sales growth. ROA is the mean of prior five years' return on assets (net income divided by total assets). Volume is trading volume (in millions of shares). Issue is the dollar amount of the issuance of public debt or equity in the current or prior year. Ret_Var is daily stock return variance estimated over the 200 days prior to the end of the fiscal year. RD_ADV is the sum of research and development and advertising expenses scaled by sales. 


\section{Table 2 (Cont'd)}

Panel B: Means of regression variables in the pre- and post-periods around the appointment of an accounting expert to the audit committee $(n=786)$

\begin{tabular}{lcccc}
\hline Variable & Pre-Appointment & Post-Appointment & $\begin{array}{c}\text { Diff. } \\
\text { (post-pre) }\end{array}$ & $\begin{array}{c}\text { p-value for } \\
\text { Diff. }\end{array}$ \\
\hline \#Analysts & 5.365 & 6.457 & 1.092 & 0.01 \\
GOV & 0.349 & 0.417 & 0.069 & 0.05 \\
Big4 & 0.985 & 0.985 & 0.000 & 1.00 \\
MEF & 1.209 & 2.611 & 1.402 & 0.00 \\
AQ & -0.059 & -0.056 & -0.002 & 0.57 \\
Broker & 44.303 & 48.175 & 3.872 & 0.03 \\
Effort & -9.119 & -9.162 & -0.043 & 0.91 \\
Size & 7.977 & 8.257 & 0.280 & 0.00 \\
Growth & 0.115 & 0.101 & -0.014 & 0.36 \\
ROA & 0.057 & 0.047 & -0.010 & 0.03 \\
Volume & 276.419 & 451.374 & 174.955 & 0.00 \\
Issue & 74.329 & 110.225 & 35.896 & 0.02 \\
Ret_Var & 0.001 & 0.001 & 0.000 & 0.00 \\
RD_Adv & 0.040 & 0.035 & -0.005 & 0.16 \\
\hline
\end{tabular}


Table 2 (Cont'd)

Panel C: Pearson Correlations ( $n=786, p$-values are in parentheses)

\begin{tabular}{|c|c|c|c|c|c|c|c|c|c|c|c|c|c|c|}
\hline & Post_Appt & GOV & Big4 & MEF & $\mathrm{AQ}$ & Broker & Effort & Size & Growth & ROA & Volume & Issue & Ret_Var & RD_Adv \\
\hline \#Analysts & $\begin{array}{l}0.071 \\
(0.04)\end{array}$ & $\begin{array}{l}-0.046 \\
(0.19)\end{array}$ & $\begin{array}{l}0.005 \\
(0.90)\end{array}$ & $\begin{array}{l}-0.062 \\
(0.08)\end{array}$ & $\begin{array}{c}0.245 \\
(<.0001)\end{array}$ & $\begin{array}{c}-0.026 \\
(0.47)\end{array}$ & $\begin{array}{l}0.051 \\
(0.15)\end{array}$ & $\begin{array}{c}0.522 \\
(<.0001)\end{array}$ & $\begin{array}{l}0.119 \\
(0.00)\end{array}$ & $\begin{array}{l}0.004 \\
(0.90)\end{array}$ & $\begin{array}{c}0.514 \\
(<.0001)\end{array}$ & $\begin{array}{c}0.245 \\
(<.0001)\end{array}$ & $\begin{array}{c}0.253 \\
(<.0001)\end{array}$ & $\begin{array}{c}0.328 \\
(<.0001)\end{array}$ \\
\hline Post_Appt & & $\begin{array}{l}0.071 \\
(0.05)\end{array}$ & $\begin{array}{l}0.000 \\
(1.00)\end{array}$ & $\begin{array}{l}0.269 \\
(0.00)\end{array}$ & $\begin{array}{l}0.020 \\
(0.05)\end{array}$ & $\begin{array}{l}0.077 \\
(0.03)\end{array}$ & $\begin{array}{c}-0.004 \\
(0.91)\end{array}$ & $\begin{array}{l}0.105 \\
(0.00)\end{array}$ & $\begin{array}{l}-0.032 \\
(0.36)\end{array}$ & $\begin{array}{r}-0.077 \\
(0.03)\end{array}$ & $\begin{array}{l}0.133 \\
(0.00)\end{array}$ & $\begin{array}{l}0.080 \\
(0.02)\end{array}$ & $\begin{array}{l}-0.212 \\
(0.00)\end{array}$ & $\begin{array}{l}-0.050 \\
(0.16)\end{array}$ \\
\hline GOV & & & $\begin{array}{l}0.055 \\
(0.12)\end{array}$ & $\begin{array}{l}-0.046 \\
(0.20)\end{array}$ & $\begin{array}{l}-0.022 \\
(0.54)\end{array}$ & $\begin{array}{l}0.100 \\
(0.00)\end{array}$ & $\begin{array}{l}-0.005 \\
(0.89)\end{array}$ & $\begin{array}{r}-0.130 \\
(0.00)\end{array}$ & $\begin{array}{l}0.030 \\
(0.39)\end{array}$ & $\begin{array}{l}0.012 \\
(0.74)\end{array}$ & $\begin{array}{l}-0.013 \\
(0.71)\end{array}$ & $\begin{array}{l}-0.076 \\
(0.03)\end{array}$ & $\begin{array}{l}0.123 \\
(0.00)\end{array}$ & $\begin{array}{l}0.021 \\
(0.55)\end{array}$ \\
\hline Big4 & & & & $\begin{array}{l}-0.056 \\
(0.12)\end{array}$ & $\begin{array}{l}-0.041 \\
(0.25)\end{array}$ & $\begin{array}{l}-0.063 \\
(0.08)\end{array}$ & $\begin{array}{l}-0.041 \\
(0.25)\end{array}$ & $\begin{array}{c}-0.019 \\
(0.59)\end{array}$ & $\begin{array}{l}0.025 \\
(0.49)\end{array}$ & $\begin{array}{c}-0.044 \\
(0.22)\end{array}$ & $\begin{array}{l}0.040 \\
(0.26)\end{array}$ & $\begin{array}{l}0.034 \\
(0.35)\end{array}$ & $\begin{array}{l}0.043 \\
(0.23)\end{array}$ & $\begin{array}{l}0.077 \\
(0.03)\end{array}$ \\
\hline MEF & & & & & $\begin{array}{l}0.076 \\
(0.03)\end{array}$ & $\begin{array}{l}0.118 \\
(0.00)\end{array}$ & $\begin{array}{l}-0.023 \\
(0.52)\end{array}$ & $\begin{array}{l}0.262 \\
(0.00)\end{array}$ & $\begin{array}{l}-0.089 \\
(0.01)\end{array}$ & $\begin{array}{c}-0.015 \\
(0.67)\end{array}$ & $\begin{array}{l}0.072 \\
(0.04)\end{array}$ & $\begin{array}{l}0.225 \\
(0.00)\end{array}$ & $\begin{array}{l}-0.209 \\
(0.00)\end{array}$ & $\begin{array}{l}-0.060 \\
(0.09)\end{array}$ \\
\hline AQ & & & & & & $\begin{array}{l}0.115 \\
(0.00)\end{array}$ & $\begin{array}{l}-0.246 \\
(0.00)\end{array}$ & $\begin{array}{l}0.116 \\
(0.00)\end{array}$ & $\begin{array}{l}-0.115 \\
(0.00)\end{array}$ & $\begin{array}{c}-0.065 \\
(0.07)\end{array}$ & $\begin{array}{l}0.242 \\
(0.00)\end{array}$ & $\begin{array}{l}-0.024 \\
(0.51)\end{array}$ & $\begin{array}{l}-0.224 \\
(0.00)\end{array}$ & $\begin{array}{l}-0.366 \\
(0.00)\end{array}$ \\
\hline Broker & & & & & & & $\begin{array}{l}-0.505 \\
(0.00)\end{array}$ & $\begin{array}{l}0.149 \\
(0.00)\end{array}$ & $\begin{array}{l}-0.075 \\
(0.03)\end{array}$ & $\begin{array}{l}-0.147 \\
<.0001\end{array}$ & $\begin{array}{r}-0.089 \\
(0.01)\end{array}$ & $\begin{array}{l}0.082 \\
(0.02)\end{array}$ & $\begin{array}{l}-0.041 \\
(0.25)\end{array}$ & $\begin{array}{l}-0.069 \\
(0.05)\end{array}$ \\
\hline Effort & & & & & & & & $\begin{array}{c}-0.051 \\
(0.16)\end{array}$ & $\begin{array}{c}-0.004 \\
(0.91)\end{array}$ & $\begin{array}{c}0.133 \\
(0.00)\end{array}$ & $\begin{array}{l}0.169 \\
(0.00)\end{array}$ & $\begin{array}{c}-0.034 \\
(0.34)\end{array}$ & $\begin{array}{l}0.194 \\
(0.00)\end{array}$ & $\begin{array}{l}0.263 \\
(0.00)\end{array}$ \\
\hline Size & & & & & & & & & $\begin{array}{l}0.095 \\
(0.01)\end{array}$ & $\begin{array}{c}0.179 \\
(0.00)\end{array}$ & $\begin{array}{l}0.554 \\
(0.00)\end{array}$ & $\begin{array}{l}0.512 \\
(0.00)\end{array}$ & $\begin{array}{r}-0.122 \\
(0.00)\end{array}$ & $\begin{array}{l}0.167 \\
(0.00)\end{array}$ \\
\hline Growth & & & & & & & & & & $\begin{array}{c}0.190 \\
(0.00)\end{array}$ & $\begin{array}{c}-0.015 \\
(0.67)\end{array}$ & $\begin{array}{c}0.039 \\
(0.28)\end{array}$ & $\begin{array}{l}0.066 \\
(0.06)\end{array}$ & $\begin{array}{l}-0.011 \\
(0.76)\end{array}$ \\
\hline ROA & & & & & & & & & & & $\begin{array}{l}-0.077 \\
(0.03)\end{array}$ & $\begin{array}{l}-0.033 \\
(0.36)\end{array}$ & $\begin{array}{l}-0.202 \\
(0.00)\end{array}$ & $\begin{array}{l}0.000 \\
(0.99)\end{array}$ \\
\hline Volume & & & & & & & & & & & & $\begin{array}{c}0.472 \\
(0.00)\end{array}$ & $\begin{array}{l}0.275 \\
(0.00)\end{array}$ & $\begin{array}{c}0.349 \\
(0.00)\end{array}$ \\
\hline Issue & & & & & & & & & & & & & $\begin{array}{l}0.037 \\
(0.30)\end{array}$ & $\begin{array}{l}0.031 \\
(0.39)\end{array}$ \\
\hline Ret_Var & & & & & & & & & & & & & & $\begin{array}{l}0.323 \\
(0.00)\end{array}$ \\
\hline
\end{tabular}


Table 3

Relation between Accounting Expertise on the Audit Committee and Analyst Following

\begin{tabular}{lcc}
\hline & \multicolumn{2}{c}{ \#Analysts } \\
Independent Variable & Coeff. Est. & p-value \\
\hline Intercept & -0.8360 & 0.00 \\
Post_Appt & 0.3706 & 0.00 \\
GOV & 0.0117 & 0.75 \\
Broker & -0.0003 & 0.77 \\
Effort & -0.0044 & 0.41 \\
Size & 0.3555 & 0.00 \\
Growth & 0.0813 & 0.25 \\
ROA & -0.7984 & 0.00 \\
Volume & 0.0001 & 0.00 \\
Issue & -0.0002 & 0.03 \\
Ret_Var & 135.6152 & 0.00 \\
RD_ADV & 2.4107 & 0.00 \\
Year fixed effects & \multicolumn{2}{c}{ Yes } \\
Firm fixed effects & \multicolumn{2}{c}{ Yes } \\
N & \multicolumn{2}{c}{0.486} \\
Pseudo R ${ }^{2}$ & \multicolumn{2}{c}{}
\end{tabular}

This table provides results for $\mathrm{H} 1$, the relation between accounting expertise on the audit committee and analyst following (\#Analysts). We use a Poisson model and estimate the regression with robust standard errors by firm clusters. See Table 2 for variable definitions. 
Table 4

Analysis of Potential Channels through which Audit Committee Accounting Expertise impacts Analyst Following

\begin{tabular}{|c|c|c|c|c|c|c|c|c|c|c|}
\hline \multirow[b]{2}{*}{ Independent Variable } & \multicolumn{2}{|c|}{$\begin{array}{c}\text { \#Analysts } \\
\text { Model } 1 \\
\end{array}$} & \multicolumn{2}{|c|}{$\begin{array}{c}\text { \#Analysts } \\
\text { Model } 2 \\
\end{array}$} & \multicolumn{2}{|c|}{$\begin{array}{c}\text { \#Analysts } \\
\text { Model } 3 \\
\end{array}$} & \multicolumn{2}{|c|}{$\begin{array}{c}\text { \#Analysts } \\
\text { Model } 4 \\
\end{array}$} & \multicolumn{2}{|c|}{$\begin{array}{c}\text { \#Analysts } \\
\text { Model } 5 \\
\end{array}$} \\
\hline & Coeff. Est. & p-value & Coeff. Est. & p-value & Coeff. Est. & $\mathrm{p}$-value & Coeff. Est. & $\mathrm{p}$-value & Coeff. Est. & p-value \\
\hline Intercept & -0.8360 & 0.00 & -0.4520 & 0.14 & -0.8333 & 0.00 & -0.8319 & 0.00 & -0.4402 & 0.15 \\
\hline Post_Appt & 0.3706 & 0.00 & 0.3838 & 0.00 & 0.3775 & 0.00 & 0.2529 & 0.00 & 0.0412 & 0.87 \\
\hline Post_Appt * Big4 & & & 0.2867 & 0.25 & & & & & 0.3119 & 0.21 \\
\hline Big4 & & & -0.3737 & 0.11 & & & & & -0.3747 & 0.11 \\
\hline Post_Appt $*$ MEF & & & & & -0.0024 & 0.87 & & & 0.0005 & 0.97 \\
\hline MEF & & & & & 0.0053 & 0.69 & & & 0.0033 & 0.80 \\
\hline Post_Appt * AQ & & & & & & & 0.3389 & 0.08 & 0.3627 & 0.05 \\
\hline $\mathrm{AQ}$ & & & & & & & 0.1652 & 0.09 & 0.2836 & 0.08 \\
\hline Controls & \multicolumn{2}{|c|}{ Yes } & \multicolumn{2}{|c|}{ Yes } & \multicolumn{2}{|c|}{ Yes } & \multicolumn{2}{|c|}{ Yes } & \multicolumn{2}{|c|}{ Yes } \\
\hline Year fixed effects & \multicolumn{2}{|c|}{ Yes } & \multicolumn{2}{|c|}{ Yes } & \multicolumn{2}{|c|}{ Yes } & \multicolumn{2}{|c|}{ Yes } & \multicolumn{2}{|c|}{ Yes } \\
\hline Firm fixed effects & \multicolumn{2}{|c|}{ Yes } & \multicolumn{2}{|c|}{ Yes } & \multicolumn{2}{|c|}{ Yes } & \multicolumn{2}{|c|}{ Yes } & \multicolumn{2}{|c|}{ Yes } \\
\hline $\mathrm{N}$ & \multicolumn{2}{|c|}{786} & \multicolumn{2}{|c|}{786} & \multicolumn{2}{|c|}{786} & \multicolumn{2}{|c|}{786} & \multicolumn{2}{|c|}{786} \\
\hline Pseudo $\mathrm{R}^{2}$ & \multicolumn{2}{|c|}{0.436} & \multicolumn{2}{|c|}{0.452} & \multicolumn{2}{|c|}{0.453} & \multicolumn{2}{|c|}{0.460} & \multicolumn{2}{|c|}{0.463} \\
\hline
\end{tabular}

This table provides an assessment of three potential channels through which accounting expertise impacts analyst following (\#Analysts). Model 1 is our baseline model that was reported in Table 3. Model 2 tests the audit quality (Big4 indicator variable $=1$ for Big 4 firm) channel. Model 3 tests the frequency of management earnings forecasts (MEF) channel, Model 4 tests the accrual quality (AQ) channel, and Model 5 is the full model that controls for all three potential channels. Results for control variables are omitted for brevity. We use a Poisson model and estimate regressions with robust standard errors by firm clusters. See Table 2 for detailed definitions of the variables. 
Table 5

Impact of Accounting Expertise on Analyst Forecast Error and Forecast Dispersion

\begin{tabular}{lcccc}
\hline & \multicolumn{2}{c}{ Forecast Error } & \multicolumn{2}{c}{$\begin{array}{c}\text { Forecast Dispersion } \\
\text { Model 1 }\end{array}$} \\
\cline { 2 - 5 } Independent Variable 2 \\
\cline { 2 - 5 } & Coeff. Est. & p-value & Coeff. Est. & p-value \\
\hline Intercept & 0.0068 & 0.00 & 0.0078 & 0.00 \\
Post_Appt & -0.0006 & 0.07 & -0.0006 & 0.02 \\
GOV & -0.0003 & 0.41 & -0.0001 & 0.60 \\
Broker & 0.0000 & 0.28 & 0.0000 & 0.07 \\
Effort & -0.0001 & 0.05 & -0.0001 & 0.01 \\
Size & -0.0004 & 0.01 & -0.0003 & 0.02 \\
Growth & 0.0014 & 0.14 & 0.0003 & 0.64 \\
ROA & -0.0162 & 0.00 & -0.0113 & 0.00 \\
Issue & 0.0000 & 0.55 & 0.0000 & 0.84 \\
Ret_Var & 0.6115 & 0.14 & 0.3148 & 0.11 \\
RD_ADV & 0.0056 & 0.24 & 0.0018 & 0.54 \\
\#Analysts & -0.0001 & 0.09 & -0.0001 & 0.07 \\
& & & & \\
Year fixed effects & Yes & & Yes & \\
Firm fixed effects & Yes & & Yes & \\
N & 786 & & 768 & \\
Pseudo R & 0.254 & & 0.307 & \\
\hline
\end{tabular}

This table provides an assessment of the impact of accounting expertise on analyst forecast errors and dispersion. Forecast Error is the absolute value of the median consensus estimate of annual earnings per share (EPS) less actual EPS scaled by stock price at the time of the forecast. Forecast Dispersion is the standard deviation of analysts' annual earnings forecast scaled by stock price at the time of the forecast. Forecast Error and Dispersion are measured at same time as \#Analysts. We adjust Forecast Error and Forecast Dispersion by subtracting the firm's industry medians. All other variables are defined in Table 2. We estimate regressions with robust standard errors by firm clusters. 
Table 6

Analysis of Potential Channels through which Accounting Expertise Impacts Analyst Forecast Properties

Panel A: Forecast Error

\begin{tabular}{|c|c|c|c|c|c|c|c|c|c|c|}
\hline & \multicolumn{10}{|c|}{ Forecast Error } \\
\hline & \multicolumn{2}{|c|}{ Model 1} & \multicolumn{2}{|c|}{ Model 2} & \multicolumn{2}{|c|}{ Model 3} & \multicolumn{2}{|c|}{ Model 4} & \multicolumn{2}{|c|}{ Model 5} \\
\hline & Coeff. Est. & p-value & Coeff. Est. & p-value & Coeff. Est. & p-value & Coeff. Est. & p-value & Coeff. Est. & p-value \\
\hline Intercept & 0.0078 & 0.00 & 0.0115 & 0.00 & 0.0078 & 0.00 & 0.0074 & 0.00 & 0.0092 & 0.00 \\
\hline Post_Appt & -0.0006 & 0.06 & -0.0008 & 0.09 & -0.0006 & 0.08 & -0.0004 & 0.33 & -0.0003 & 0.36 \\
\hline Post_Appt $*$ Big4 & & & 0.0001 & 0.73 & & & & & -0.0001 & 0.57 \\
\hline Big4 & & & -0.0018 & 0.00 & & & & & -0.0019 & 0.00 \\
\hline Post_Appt $*$ MEF & & & & & 0.0000 & 0.99 & & & 0.0000 & 0.95 \\
\hline MEF & & & & & -0.0001 & 0.56 & & & -0.0001 & 0.32 \\
\hline Post_Appt $*$ AQ & & & & & & & -0.0037 & 0.07 & -0.0037 & 0.08 \\
\hline AQ & & & & & & & -0.0039 & 0.10 & -0.0044 & 0.10 \\
\hline Control Variables & \multicolumn{2}{|c|}{ Yes } & \multicolumn{2}{|c|}{ Yes } & \multicolumn{2}{|c|}{ Yes } & \multicolumn{2}{|c|}{ Yes } & \multicolumn{2}{|c|}{ Yes } \\
\hline Year fixed effects & \multicolumn{2}{|c|}{ Yes } & \multicolumn{2}{|c|}{ Yes } & \multicolumn{2}{|c|}{ Yes } & \multicolumn{2}{|c|}{ Yes } & \multicolumn{2}{|c|}{ Yes } \\
\hline Firm fixed effects & \multicolumn{2}{|c|}{ Yes } & \multicolumn{2}{|c|}{ Yes } & \multicolumn{2}{|c|}{ Yes } & \multicolumn{2}{|c|}{ Yes } & \multicolumn{2}{|c|}{ Yes } \\
\hline $\mathrm{N}$ & \multicolumn{2}{|c|}{786} & \multicolumn{2}{|c|}{786} & \multicolumn{2}{|c|}{786} & \multicolumn{2}{|c|}{786} & \multicolumn{2}{|c|}{786} \\
\hline Pseudo $\mathrm{R}^{2}$ & \multicolumn{2}{|c|}{0.259} & \multicolumn{2}{|c|}{0.261} & \multicolumn{2}{|c|}{0.260} & \multicolumn{2}{|c|}{0.261} & \multicolumn{2}{|c|}{0.262} \\
\hline
\end{tabular}




\section{Table 6 (Cont'd)}

Panel B: Forecast Dispersion

\begin{tabular}{|c|c|c|c|c|c|c|c|c|c|c|}
\hline & \multicolumn{10}{|c|}{ Forecast Dispersion } \\
\hline & \multicolumn{2}{|c|}{ Model 1} & \multicolumn{2}{|c|}{ Model 2} & \multicolumn{2}{|c|}{ Model 3} & \multicolumn{2}{|c|}{ Model 4} & \multicolumn{2}{|c|}{ Model 5} \\
\hline & Coeff. Est. & $\mathrm{p}$-value & Coeff. Est. & p-value & Coeff. Est. & $\mathrm{p}$-value & Coeff. Est. & $\mathrm{p}$-value & Coeff. Est. & $\mathrm{p}$-value \\
\hline Intercept & 0.0095 & 0.00 & 0.0163 & 0.00 & 0.0094 & 0.00 & 0.0097 & 0.00 & 0.0109 & 0.00 \\
\hline Post_Appt & -0.0006 & 0.02 & -0.0007 & 0.05 & -0.0005 & 0.06 & -0.0005 & 0.11 & 0.0001 & 0.84 \\
\hline Post_Appt * Big4 & & & -0.0002 & 0.74 & & & & & -0.0003 & 0.48 \\
\hline Big4 & & & -0.0014 & 0.07 & & & & & -0.0013 & 0.08 \\
\hline Post_Appt* MEF & & & & & -0.0001 & 0.56 & & & 0.0000 & 0.60 \\
\hline MEF & & & & & 0.0000 & 0.99 & & & -0.0001 & 0.19 \\
\hline Post_Appt*AQ & & & & & & & -0.0036 & 0.08 & -0.0039 & 0.09 \\
\hline AQ & & & & & & & -0.0017 & 0.32 & -0.0018 & 0.37 \\
\hline Control Variables & \multicolumn{2}{|c|}{ Yes } & \multicolumn{2}{|c|}{ Yes } & \multicolumn{2}{|c|}{ Yes } & \multicolumn{2}{|c|}{ Yes } & \multicolumn{2}{|c|}{ Yes } \\
\hline Year fixed effects & \multicolumn{2}{|c|}{ Yes } & \multicolumn{2}{|c|}{ Yes } & \multicolumn{2}{|c|}{ Yes } & \multicolumn{2}{|c|}{ Yes } & \multicolumn{2}{|c|}{ Yes } \\
\hline Firm fixed effects & \multicolumn{2}{|c|}{ Yes } & \multicolumn{2}{|c|}{ Yes } & \multicolumn{2}{|c|}{ Yes } & \multicolumn{2}{|c|}{ Yes } & \multicolumn{2}{|c|}{ Yes } \\
\hline $\mathrm{N}$ & \multicolumn{2}{|c|}{768} & \multicolumn{2}{|c|}{768} & \multicolumn{2}{|c|}{768} & \multicolumn{2}{|c|}{768} & \multicolumn{2}{|c|}{768} \\
\hline Pseudo $\mathrm{R}^{2}$ & \multicolumn{2}{|c|}{0.336} & \multicolumn{2}{|c|}{0.337} & \multicolumn{2}{|c|}{0.340} & \multicolumn{2}{|c|}{0.338} & \multicolumn{2}{|c|}{0.343} \\
\hline
\end{tabular}

This table provides an assessment of three potential channels through which accounting expertise impacts analyst forecast error (Panel A) and analyst forecast dispersion (Panel B). Model 1 is our baseline regression that was reported in Table 5. Model 2 tests the audit quality (Big4 indicator variable $=1$ for Big 4 firm) channel. Model 3 tests the frequency of management earnings forecasts (MEF) channel, Model 4 tests the accrual quality (AQ) channel, and Model 5 is the full model that controls for all three potential channels. Results for control variables are omitted for brevity. We use an OLS model and estimate regressions with robust standard errors by firm clusters. See Tables 2 and 5 for detailed definitions of the variables. 
Table 7

Capital Market Impact of Accounting Expertise on the Audit Committee

Panel A: Trading Volume

\begin{tabular}{|c|c|c|c|c|}
\hline \multirow[b]{2}{*}{$\begin{array}{l}\text { Independent } \\
\text { Variable }\end{array}$} & \multicolumn{2}{|c|}{$\begin{array}{c}\text { Log_Vol } \\
\text { Model } 1\end{array}$} & \multicolumn{2}{|c|}{$\begin{array}{l}\text { Log_Vol } \\
\text { Model } 2 \\
\end{array}$} \\
\hline & Coeff. Est. & p-value & Coeff. Est. & $\mathrm{p}$-value \\
\hline Intercept & -1.6633 & 0.00 & -2.3174 & 0.00 \\
\hline Post_Appt & 0.0697 & 0.04 & 0.0801 & 0.03 \\
\hline Log_MV & 0.9716 & 0.00 & 0.9742 & 0.00 \\
\hline $\mathrm{BM}$ & -0.0032 & 0.98 & -0.0762 & 0.54 \\
\hline Log_Price & -0.5532 & 0.00 & -0.6395 & 0.00 \\
\hline Idio_Risk & 51.6947 & 0.00 & 49.6669 & 0.00 \\
\hline Inst_Holdings & & & 1.0735 & 0.00 \\
\hline Forecast Error & & & -8.0370 & 0.13 \\
\hline Forecast Dispersion & & & 20.6300 & 0.04 \\
\hline Year fixed effects & \multicolumn{2}{|c|}{ Yes } & \multicolumn{2}{|c|}{ Yes } \\
\hline Firm fixed effects & \multicolumn{2}{|c|}{ Yes } & \multicolumn{2}{|c|}{ Yes } \\
\hline $\mathrm{N}$ & \multicolumn{2}{|c|}{786} & \multicolumn{2}{|c|}{732} \\
\hline Adjusted $\mathrm{R}^{2}$ & \multicolumn{2}{|c|}{0.899} & \multicolumn{2}{|c|}{0.908} \\
\hline
\end{tabular}

Panel B: Liquidity Risk

\begin{tabular}{|c|c|c|c|c|}
\hline \multirow{2}{*}{$\begin{array}{l}\text { Independent } \\
\text { Variable }\end{array}$} & \multicolumn{2}{|c|}{$\begin{array}{l}\text { Liquidity Risk } \\
\text { Model } 1\end{array}$} & \multicolumn{2}{|c|}{$\begin{array}{l}\text { Liquidity Risk } \\
\text { Model } 2\end{array}$} \\
\hline & Coeff. Est. & $p$-value & Coeff. Est. & $\mathrm{p}$-values \\
\hline Intercept & 0.0195 & 0.62 & 0.0458 & 0.31 \\
\hline Post_Appt & -0.0009 & 0.04 & -0.0008 & 0.07 \\
\hline Log_MV & -0.0006 & 0.08 & -0.0001 & 0.09 \\
\hline BM & -0.0054 & 0.49 & -0.0033 & 0.69 \\
\hline Log_Price & -0.0065 & 0.03 & -0.0024 & 0.06 \\
\hline Idio_Risk & 0.4879 & 0.36 & 0.5874 & 0.29 \\
\hline Inst_Holdings & & & -0.0453 & 0.07 \\
\hline Forecast Error & & & 0.4240 & 0.07 \\
\hline Forecast Dispersion & & & 0.1827 & 0.91 \\
\hline Year fixed effects & \multicolumn{2}{|c|}{ Yes } & \multicolumn{2}{|c|}{ Yes } \\
\hline Firm fixed effects & \multicolumn{2}{|c|}{ Yes } & \multicolumn{2}{|c|}{ Yes } \\
\hline $\mathrm{N}$ & \multicolumn{2}{|c|}{786} & \multicolumn{2}{|c|}{732} \\
\hline Adjusted $\mathrm{R}^{2}$ & \multicolumn{2}{|c|}{0.045} & \multicolumn{2}{|c|}{0.050} \\
\hline
\end{tabular}


This table provides the results for tests of $\mathrm{H} 2$, the relation between audit committee accounting expertise and both trading volume and liquidity risk. Log_Vol is the natural $\log$ of the number of shares (in millions) traded during the fiscal year. Liquidity Risk is calculated as (Number of zero daily volumes in prior 12 months + $1 /(12$-month turnover*11,000)) *252/Number of trading days in prior 12 months, where 12-month turnover is the sum of the ratio of the number of shares traded on a day to the number of shares outstanding at the end of the day. All other variables are defined in Table 2. We estimate regressions with robust standard errors by firm clusters. 